\title{
The location strategies of multinationals from emerging countries in the EU regions
}

Citation for published version (APA):

Crescenzi, R., Pietrobelli, C., \& Rabellotti, R. (2015). The location strategies of multinationals from emerging countries in the EU regions. UNU-MERIT. UNU-MERIT Working Papers No. 009

Document status and date:

Published: 01/01/2015

Document Version:

Publisher's PDF, also known as Version of record

\section{Please check the document version of this publication:}

- A submitted manuscript is the version of the article upon submission and before peer-review. There can be important differences between the submitted version and the official published version of record.

People interested in the research are advised to contact the author for the final version of the publication, or visit the DOI to the publisher's website.

- The final author version and the galley proof are versions of the publication after peer review.

- The final published version features the final layout of the paper including the volume, issue and page numbers.

Link to publication

\footnotetext{
General rights rights.

- You may freely distribute the URL identifying the publication in the public portal. please follow below link for the End User Agreement:

www.umlib.nl/taverne-license

Take down policy

If you believe that this document breaches copyright please contact us at:

repository@maastrichtuniversity.nl

providing details and we will investigate your claim.
}

Copyright and moral rights for the publications made accessible in the public portal are retained by the authors and/or other copyright owners and it is a condition of accessing publications that users recognise and abide by the legal requirements associated with these

- Users may download and print one copy of any publication from the public portal for the purpose of private study or research.

- You may not further distribute the material or use it for any profit-making activity or commercial gain

If the publication is distributed under the terms of Article $25 \mathrm{fa}$ of the Dutch Copyright Act, indicated by the "Taverne" license above, 


\section{UNITED NATIONS \\ UNIVERSITY}

UNU-MERIT

\section{Working Paper Series}

\section{\#2015-009}

The location strategies of multinationals from emerging countries in the EU regions

Riccardo Crescenzi, Carlo Pietrobelli and Roberta Rabellotti

Maastricht Economic and social Research institute on Innovation and Technology (UNU-MERIT) email: info@merit.unu.edu | website: http://www.merit.unu.edu 


\section{UNU-MERIT Working Papers}

ISSN 1871-9872

Maastricht Economic and social Research Institute on Innovation and Technology, UNU-MERIT

\section{Maastricht Graduate School of Governance}

MGSoG

UNU-MERIT Working Papers intend to disseminate preliminary results of research carried out at UNU-MERIT and MGSoG to stimulate discussion on the issues raised. 


\title{
The Location Strategies of Multinationals from Emerging
}

\section{Countries in the EU Regions *}

\author{
Riccardo Crescenzi \\ Department of Geography \\ and Environment \\ London School of \\ Economics \\ United Kingdom \\ Tel. +44-207955-6720 \\ r.crescenzi@,lse.ac.uk
}

\author{
Carlo Pietrobelli \\ Inter-American \\ Development Bank, \\ Washington D.C., USA, \\ and Università Roma Tre, \\ Italy \\ Tel.+1-202-623-2423 \\ carlop@iadb.org
}

\author{
Roberta Rabellotti \\ Dipartimento di Scienze \\ Politiche \\ e Sociali \\ Università di Pavia, \\ Italy \\ Tel. +39-0382984038 \\ roberta.rabellotti@unipv.it
}

\begin{abstract}
This paper contributes to the current debate in both Economic Geography and International Business on the nature and strategies of Multinational Enterprises (MNEs) from emerging countries (EMNEs). The paper fills a very relevant gap in the existing literature by shedding new light on the location strategies of EMNEs at the national and regional level, looking at their investment drivers and systematically comparing them with those of multinationals from advanced countries (AMNEs).

The empirical analysis looks at the location choices of MNEs in the European Union (EU-25) regions and unveils that EMNEs follow distinctive location strategies. Their attraction into large regional markets is similar to AMNEs as well as their irresponsiveness to efficiency seeking motives. Conversely, the most knowledge-intensive investments of EMNEs respond mainly to two 'attraction' factors: strategic assets (in the form of local technological dynamism) and the agglomeration of foreign investments in the same business functions. In addition, both the national and the regional levels are simultaneously relevant to EMNEs decisions.
\end{abstract}

\section{JEL Classification: F21, F23, O33, R12, R58}

Keywords: Multinationals, Emerging Countries, Regions, European Union

\footnotetext{
* The opinions expressed in this paper are those of the authors and do not necessarily reflect the views of the Inter-American Development Bank, its Board of Directors, or the countries they represent. The authors wish to thank participants at the 2014 EUROLIO Geography of Innovation workshop in Utrecht and at the North American Regional Science Conference in Washington D.C. for their helpful comments. All errors and omissions are our own.
} 


\section{INTRODUCTION}

The unprecedented international expansion of firms from emerging economies is one of the most striking recent evolutions in the world Foreign Direct Investments (FDIs) landscape. Outflows of FDIs from developing economies have reached the record level of $\$ 553$ billion in 2013, corresponding to 39\% of global FDI outflows, up from 16\% in 2007 (UNCTAD, 2014). Multinational enterprises (MNEs) from emerging countries (EMNEs) have attracted a mounting interest in the academic literature. Scholars have looked at the reasons for expansion of EMNEs, at their similarities and differences with advanced countries' MNEs (AMNEs), and at the coherence of their behaviour with the predictions of mainstream theories about multinational firms (Ramamurti and Singh, 2009). More than 30 years ago, the seminal contributions in this now thriving literature suggested that MNEs from developing countries possessed specific and distinctive features that distinguished them from MNEs based in developed countries (e.g. Kumar and McLeod, 1981; Lall and Chen, 1983). In the 1970s and 1980s the first 'wave' of outward FDI from developing countries (such as India, Russia, Argentina) was pioneered by MNEs - so it was argued - that differed considerably from that of 'conventional' industrialised countries MNEs, in terms of their ownership advantages, motivation, geographical orientation and mode of overseas activity.

A second wave of FDI by EMNEs emerged in the 1990s and was considered as the result of an evolutionary process from the first wave (Dunning, 1998). This second surge targeted simultaneously less-developed countries - in order to exploit their comparative advantages in activities intensive in natural resources and cheap labour - and more developed countries with both market-seeking and asset-augmenting motives. ${ }^{1}$

\footnotetext{
${ }^{1}$ Asset-augmenting activities have as their primary purpose the generation of new knowledge, which augments existing competences, whether this is through their own (formal) R\&D activities, or through other nonhierarchical means in partnership with other economic actors (Narula, 2010).
} 
Looking at the most recent waves of EMNEs investments in the 2000s, Narula (2010) suggests that they should be seen as an intermediate stage in the long-term evolution of MNEs' activities fostered by increased market liberalisations and greater cross-border competition. In this perspective EMNEs would progressively converge towards AMNEs in terms of their behaviour and strategies: over the past 30 years EMNEs have developed from 'infant' into 'adolescent' MNEs and they are currently in the process of evolving into fully 'mature' MNEs (Ramamurti, 2012). In contrast, other authors argue that the most recent 'third wave' of EMNEs investments show remarkable structural differences with no sign of 'convergence' towards the same 'model' (Mathews, 2006 and Gammeltoft, 2008).

This paper aims to contribute to this ongoing debate by shedding new light on one particular aspect of EMNEs strategies that remains significantly under-explored in the existing literature both in International Business Studies and Economic Geography (Dunning 2009): their international location decisions at both the national and sub-national levels. The choice of appropriate locations for their subsidiaries is strictly related to the internalisation motivations of MNEs (Belderbos et al, 2011; Dunning, 2009) and a systematic comparative analysis of the spatial location behaviour of EMNEs and AMNEs makes it possible to unveil similarities and differences in their investment motives comparing the importance of national-level vs. regional characteristics. The paper aims to answer a set of fundamental questions linked to the location strategies and spatial behaviour of EMNEs: what are the characteristics of the destination areas that matter the most for EMNEs? Are these local attraction factors and behaviours different from the drivers of AMNEs' investments? Do EMNEs target primarily countries or specific regions/sub-national units?

In order to answer these questions the paper bridges the Economic Geography and International Business Studies literature. The former has extensively studied the sub-national location strategies of MNEs by means of both qualitative and quantitative methods but has 
devoted very limited attention to EMNEs location. The latter has extensively debated the nature and strategies of EMNEs with no attention to the subnational dimension of location strategies. The empirical analysis systematically compares the location drivers of EMNEs and AMNEs investments in the regions of the European Union (EU-25) over the 2003-2008 (precrisis) period. The EU is a unique case study for such a comparative study: it is a large recipient of FDI from both developed and emerging countries and it is an integrated economic space (single market) with substantial economic heterogeneity both at the member state/country level and at the sub-national/regional level. The quantitative analysis, based on a Nested Logit approach, makes it possible to explore the location determinants of a large number of investments, assessing the relative importance of the investments drivers at the centre of the theoretical debate. The probability of a region to be chosen as a destination of foreign investments is estimated as a function of its economic wealth (in order to capture the market seeking investment motives), its technological dynamism and broader socio-economic 'innovation proneness' (in order to capture strategic asset seeking motivation), its labour market conditions (efficiency seeking motivation) and the regional agglomeration of foreign investments (in order to capture the 'imitative' behaviour of MNEs following other MNEs in the same sector and/or activity as in Dunning, 2009). The empirical analysis also tests the nested structure of the investment decisions, shedding light on the relative importance of national vs. regional location factors for AMNEs vs. EMNEs (Beugelsdijk and Mudambi, 2013).

Overall, the innovative contribution of the paper to the existing literature is two-fold. First the paper offers a systematic comparative analysis of the similarities and differences among the location strategies of AMNEs and EMNEs. Second the paper provides an examination of the diverse role of national vs. regional factors in these strategies that is also unexplored in the existing literature. The empirical results suggest that AMNEs and EMNEs search for a 
diverse set of drivers when investing in the EU regions: there is no 'general' common model for the behaviour of MNEs and EMNEs do display some relevant behavioural differences when compared to other Multinationals. While for market seeking investments EMNEs resemble their North American counterparts when it comes to strategic asset seeking investments EMNEs do follow a distinct logic in their location strategies. EMNEs are attracted by the availability of technological competences (i.e. patent intensity) only when their subsidiaries pursue more sophisticated and technology-intensive functions. The structural and socio-institutional pre-conditions for establishing fully functional regional systems of innovation - 'soft' factors in regional innovation - are not relevant to EMNEs. Conversely EMNEs share some behavioural similarities with AMNEs in their response to the spatial agglomeration of investments: they do tend to invest in the regions where investments in the same function or sector are already present. The results also suggest that a regional perspective is highly relevant to the comparative analysis of MNEs' behaviour: regional and national drivers are differently valued by MNEs from different origins.

The paper is organised as follows. The next section reviews the literature dealing with the location of MNEs introducing the determinants analysed in the empirical analysis with special reference to the expected behavioural differences between AMNEs and EMNEs. Section 3 introduces the empirical strategy and the dataset. The empirical results are presented in Section 4. Section 5 concludes with some policy considerations and an agenda for future (possibly inter-disciplinary) research in this field.

\section{A FRAMEWORK FOR COMPARATIVE ANALYSIS: MNES AND THEIR LOCATION DRIVERS}

There is a widespread consensus in the literature that the understanding of the location behaviour of MNEs is still underdeveloped. Referring to the Ownership-Location- 
Internalization (OLI) paradigm developed by Dunning (1977), the economic and international business theory has dealt widely with the questions related to the why a firm becomes a multinational $(\mathrm{O})$ and how it carries out its international adventure (I) but so far the discussion about where it goes to internationalise its activities (L) has remained rather fuzzy (Iammarino and McCann, 2013; McCann and Mudambi, 2005). Nevertheless, Dunning (2009) notes that the location choices of MNEs may by itself become an ownership advantage and contribute to augment firms' assets.

Beugelsdijk and Mudambi (2013) identify a significant limitation of the analysis of MNEs location choices in the almost exclusive national-level focus of the existing studies. Countries have been considered as the natural focus of MNEs location analysis due to the predominant role that national borders and active investment policies at the country level have traditionally played in explaining the geography of MNEs. Conversely, nowadays "MNEs location decisions are becoming increasingly complex and dependent on the variety and quality of highly localized assets" (Iammarino and McCann, 2013: 360). The interaction between the process of technological change - that has increased the geographical fragmentation possibilities of the production process - and institutional evolution - resulting in a global trend towards the devolution of power and spending capabilities from national to sub-national units - has dramatically increased the importance of sub-national drivers of investments decisions. In this context it is critical to extend the location analysis of MNEs, integrating the factors explaining the within-country variation in investment drivers with those related to the between-country variation (McCann and Mudambi, 2005; Beugelsdijk and Mudambi 2013). When looking in particular at EMNEs, the analysis of their location strategies has remained very limited and it has mainly focused on the alternative between the decision to invest in advanced economies vs. other developing/emerging countries. The main conclusion of the available literature is that EMNEs direct their FDIs towards developed countries when they 
aim at accessing new technologies and when their main motivation is market access, on the contrary they invest in developing countries when they have labour seeking motivations (Kedia et al. 2012; Makino et al, 2002). In addition the literature emphasises that the likelihood for MNEs to invest in a particular location is also influenced by the characteristics and the capabilities of the investing company. Therefore, the different nature of EMNEs and AMNEs may justify the diverse importance they attribute to national and sub-national drivers (Cuervo-Cazurra and Ramamurti, 2014)

In order to move beyond the simple location behaviour dichotomy South-South vs. SouthNorth investments, it is useful to look at the literature on the location strategies of MNEs in order to identify (and operationalise) the key 'motives' attracting foreign investments in different locations. The comparison of the relative importance of these motives for AMNEs and EMNs makes it possible to shed light on the heterogeneity (if any) of their preferences in terms of location strategies.

The analysis of the literature on location choices identifies 'market-seeking', 'strategic assetseeking' and 'efficiency-seeking' motives as well as 'imitative behaviours' leading to the spatial agglomeration of (similar) MNEs' investments.

'Market-seeking' motivations have been at the centre of the 'traditional' literature on location advantages. The existing literature suggests that both AMNEs and EMNEs are attracted by the size and the potential of their prospective host markets. Flores and Aguilera (2007) explore the host country location factors for the largest 100 US MNEs suggesting that both host country's GDP and population are significant drivers of MNEs location choice. Similar findings are presented in Loree and Guisinger (1995) in a study on the location of US FDI that confirms a positive and significant relation between investments attraction and the GDP per capita of host countries. Over and above national markets, MNEs can target specific customer segments and/or be attracted by the richest regions within countries (Beugelsdijk 
and Mudambi, 2013; Crescenzi et al. 2014). In those cases, in their location decisions MNEs take into account the subnational (i.e. regional or urban-level) characteristics of the markets rather than the national ones. Kedia et al. 2012 suggest that market-seeking motives might play an equally important role for EMNEs using their investments in advanced economies as platforms for their products to be tailored to the requirements of geographically and culturally distant partners (Goldstein, 2009). The investments undertaken in Italy by Haier - a Chinese white goods manufacturer - are a case in point: the objective of improving the capability to design, develop and manufacture products suitable for the European markets is a key driver of this EMNE's location strategy Pietrobelli et al (2011).

The expectations on the behaviour of AMNEs and EMNEs are more diversified when it comes to 'asset seeking' investments. When MNEs search for host locations endowed with specialised knowledge-related assets that are highly localised and often linked to agglomeration economies and spatially bound knowledge flows their behaviour is inherently more diversified depending on the ways in which 'internal' knowledge assets and resources can be balanced and matched with external factors (Alcacer and Delgado 2013). The search for specific localised advantages is particularly evident when the host economies offer knowledge and intangible 'L'-type advantages like for example Silicon Valley in the US or Cambridge and London in the UK, that are usually highly localised in a few sub-national units (e.g. Cantwell and Piscitello, 1999; Dunning, 2009; Iammarino and McCann, 2013). The literature suggests that this motivation is especially strong for EMNEs. Several empirical studies conducted on large samples of firms show that this is a major reason to invest in developed countries (Bertoni et al. 2013; Buckley et al. 2007). Furthermore, the intention to acquire knowledge, technology and other strategic assets (such as commercial brands and networks) is reported in case studies on well-known companies such as Haier from China and Tata from India (Duysters et al. 2009). Ramamurti and Singh (2009) add that the effective 
acquisition of strategic assets is significantly mediated by the technological capabilities of the investing firms. As shown in Makino et al. (2002) EMNEs that do not possess adequate experience are not particularly attracted towards location characterised by technological assets. Given the spatial heterogeneity of these factors, behavioural differences emerge even more clearly when analysed at the sub-national level as in this paper.

In a similar vein, 'efficiency-seeking' investments both from AMNEs and EMNEs are attracted to specific sub-national locations for reasons related to abundant labour supply in excess of local demand and availability of skilled and unskilled workers (Disdier and Mayer, 2004). However, nominal wage differentials tend to emerge more at the national rather than at the sub-national level (e.g. in the EU, nominal wages are often set by means of national-level collective employment contracts), making this factor less directly relevant to regional analysis although still captured by national controls.

Finally, both the Economic Geography and the International Business literature have emphasised the importance of 'imitative behaviours' that induce MNEs to concentrate their investments in pre-existing agglomerations of Multinational investments, often following a sectorial or a functional logic (Alfaro and Xiaoyang Chen, 2014; Crescenzi et al. 2014). Given the diversity (and the constant evolution) of their investment motives, MNEs constantly learn about the potential advantages of alternative locations by observing the entry choices of previous investors. According to Belderbos et al. (2011) if MNEs are uncertain about alternative locations they tend to follow other firms, and in particular companies from the same country and in the same industry.

MNEs also benefit from co-location with other multinationals due to agglomeration economies such as shared infrastructure, labour market pooling, availability of specialised and qualified input suppliers and service providers and localised knowledge flows (Basile et al, 2008; Devereux et al, 2007; Head et al, 1995 and 1999). In addition, MNEs locate in close 
proximity to other MNEs in order to reduce the costs of gathering information on contextspecific factors: co-location is advantageous to MNEs if knowledge inflows favouring the individual firm are larger than the outflows "lost" to the benefit of their competitors (Mariotti et al., 2010).

The benefits from co-location and agglomeration can be offset by congestion, leading to price competition and higher input and labour costs. Belderbos et al., (2011) show that local agglomeration of Japanese MNEs in Chinese provinces attracts further entry until a certain threshold is reached. After this threshold the link between local agglomeration of FDI and further entry turns negative due to increased competition on the local market and decreasing profits. In addition, agglomeration might not generate benefits per se. In contrast, the way in which advantages and disadvantages from co-location are balanced depends on the sectorial or functional similarities/congruence between the new investments and the pre-existing firms/subsidiaries. Similar firms are expected to provide the strongest informational value to other similar firms with a stronger impact on 'inexperienced' firms, more likely to mimic other 'model' firms' location choices (Belderbos et al., 2011).

With regard to EMNEs in developed countries, they have limited knowledge and little previous foreign investment experience. Therefore, we can expect that EMNEs will face high uncertainty and that they will likely follow similar firms with previous experience in the same host market (Ramamurti and Singh, 2009). In other words, agglomeration and co-location are likely to play a key role in EMNEs location decisions, due to the high informational value generated by other pre-existing foreign investments. 


\section{EMPIRICAL STRATEGY}

\subsection{The model}

In line with most of the empirical literature on the location decisions of multinational enterprises the analysis of the choice between multiple alternatives is modelled by means of a Nested Logit Model (NLM) (McFadden 1984). In the NLM the alternative locations (the EU NUTS1/2 regions in this case), are organised into subgroups - the countries to which regions belong to - and the selection process is conceived as involving two simultaneous decisions: 1 ) the choice of a country $i$ among I $\left(1 \ldots, \mathrm{i}, \ldots \mathrm{n}_{\mathrm{i}}\right)$ corresponding to the set of possible countries and 2) the selection of a specific region $J\left(1 \ldots, j, \ldots n_{i}\right)$ in the chosen $i$ country. Although simultaneous, these decisions are based on a heterogeneous set of characteristics because, given their dissimilar national characteristics (from tax systems to institutional conditions), regions in different countries cannot be considered - ceteris paribus in terms of their local conditions - perfect substitutes.

The estimated model takes the following form:

$P_{i j}=P_{j / i} P_{i}=\frac{e^{\beta X_{i j}}}{e^{I_{i}}}\left(\frac{e^{\gamma Y_{i}+\sigma_{i} I_{i}}}{\sum_{m=1}^{l} e^{\gamma Y_{m}+\sigma_{m} I_{m}}}\right)$

Where $P_{j / i}$ is the dependent variable, measuring the probability of a certain region $j$ being chosen as a destination of a foreign investment conditioned by the choice of country $I$. This depends on the characteristics of the $n_{i}$ regions belonging to country $i$. Some location characteristics vary across both countries and regions $\left(X_{i j}\right)$, while other characteristics only vary across countries $\left(Y_{i}\right) . \beta$ and $\gamma$ are the coefficients to be estimated.

In the NLM model the probability of a certain region to be chosen as a destination of a foreign investment (dependent variable) is a function of a set of two types of regional drivers: 1) regional characteristics that remain the same for all investments, such as for example the 
regional unemployment rate and the total number of investments in the region, and 2) drivers that vary with the specific investment under analysis, such as the number of regional investments in the same sector and function as the new investment.

Moreover, with the coefficients of the inclusive value $\sigma$ the model assesses the strength of the nested structure of the location process of the investments. When $\sigma=1$ regions are all equivalent options for MNEs, irrespective of the country they belong to, suggesting complete independence in the location decisions with no nested structure. If instead, $\sigma=0$ the upper nest (the country level decision) is the only relevant decision in the location choice, as all regions within the destination country are all perfect substitutes. As a consequence, by testing the nested structure of the investment decisions we are able to shed light on the relative weight the investors ascribe to national vs. regional attractors, contributing to the research agenda discussed in Beugelsdijk and Mudambi (2013) with new, original empirical evidence.

All country-level observable and unobservable characteristics (from corporate tax policies to business climate and institutional conditions) are controlled for by the national 'nested' structure of the model. Within the European Union, the degree of national level heterogeneity that can be captured with quantitative indicators is very limited and qualitative differences in terms of national-level attractiveness are prevalent and better captured when explicitly treated - as in this paper - as unobservable factors common to all the regions belonging to the same country and conceptually equivalent to 'country' fixed effects in location choices.

\subsection{The dataset}

FDI data are from fDi Markets, a database maintained by fDi Intelligence, a specialist division of the Financial Times, which monitors cross border greenfield investments covering all sectors and countries worldwide since 2003. In the period 2003-2008, the database includes around 72,000 worldwide projects with no minimum investment amount required. Our 
empirical analysis is based on the 22,065 projects undertaken by MNCs from the entire world into the EU25 countries. ${ }^{2}$ Table 1 presents the distribution of the investment projects in EU27 by country of origin. ${ }^{3}$

It is worth stressing that the individual location decisions are a more appropriate unit of analysis than the value of the investment when looking at the location strategies of multinationals and their motives because the choice of a specific country and the motivation of the investment have been shown to be largely independent from the amount of capital invested (Amighini et al., 2014; Sutherland and Anderson, 2014). Moreover, the investment size varies widely across sectors, with resource-intensive sectors showing higher average investment size than consumer goods sectors or services. This is the main reason why several empirical studies have chosen the number of deals (and not the investment size) as their unit of analysis (among others see Castellani and Pieri, 2013; Crescenzi et al., 2013; Ramasamy et al., 2012). ${ }^{4}$

The first year covered by the dataset (2003) is used as the basis for the calculation of the (lagged) cumulative number of investments and therefore is not included in the empirical analysis. The nested logit procedure only takes into account regions chosen at least once as investment destinations (Spies, 2010).

\section{[Table 1 about here]}

\footnotetext{
${ }^{2}$ The accuracy and robustness of the information reported in fDi Markets has been checked using different methodologies: a) comparison with UNCTAD information on FDI flows at the country level; b) comparison of regional-level distribution of investments with Euromonitor database, which provides information about FDI in Europe based on a completely independent source. All these checks confirm the reliability of the fDi Markets database on the spatial distribution of FDI.

${ }^{3}$ With regard to emerging countries, there is not an official definition, but there are several alternative classifications utilised by different research institutions. Different classifications are available at http://en.wikipedia.org/wiki/Emerging_markets (accessed June, 19rd 2013). In order to check the robustness of our definition of emerging in countries in the empirical analysis we have also tested an enlarged group including Argentina, Malaysia and Ukraine obtaining very similar results.

${ }^{4}$ There is an additional reason for this choice: even if the database provides information on the value of the investment, in most of the cases this is estimated.
} 
The regional analysis is based on a mix of NUTS1 and NUTS2 regions, selected in order to maximise their homogeneity in terms of the relevant socio-institutional structure and also considering data availability. Consequently, the analysis uses NUTS1 regions for Belgium, Germany and the United Kingdom and NUTS2 for all other countries (Austria, Czech Republic, Finland, France, Greece, Hungary, Italy, the Netherlands, Poland, Portugal, Slovakia, Spain). ${ }^{5}$

Furthermore, fDi Markets provides a classification of the investments in 18 functions including: Manufacturing, Logistic and Distribution, Sales and Marketing, R\&D, Headquarters. Following Defever (2006), we have aggregated them in two categories: production-oriented (PRODUCTION) and non-production functions (HQ/R\&D/SALES/DIS), including headquarters, $\mathrm{R} \& \mathrm{D}$, design, sales and marketing, logistics and distribution. Although we cannot measure directly the sophistication of these sets of functions, we reasonably assume that the non-production functions are more sophisticated and possibly more knowledge intensive, likely to bring high value added shares (Ali-Yrkkö, et al., 2011, and Kraemer et al., 2011). The location drivers of the investments from different origins are compared across the two different functional sub-samples.

\subsection{The explanatory variables}

The investment drivers included in the econometric model reflect the conceptual framework presented in the previous section and are based on the operationalisation of the various investment motives discussed above (Table A.1 in the Appendix provides detailed information about definitions and sources):

\footnotetext{
${ }^{5}$ The Nomenclature of Units for Territorial Statistics (NUTS) is a geocode standard for referencing the EU countries for statistical purposes. The NUTS-regions are based on the existing national administrative subdivisions. Countries without equivalent sub-national regions (Cyprus, Estonia, Denmark, Ireland, Latvia, Lithuania, Luxembourg and Malta) are necessarily excluded from the econometric analysis. Sweden is also excluded due to the lack of regional data for some of its regions.
} 
1) Market seeking motivation. According to the existing literature (Head and Mayer, 2004; Py and Hatem, 2009), MNEs prefer to invest in more developed core regions with relatively high Regional GDP per capita when their motivation is market seeking. This expectation holds both for AMNEs and EMNEs.

2) Strategic asset seeking motivation. We introduce two key dimensions of regional innovative dynamism: the innovation output intensity and the existence of socio-economic conditions favourable to innovation. With Patent Intensity we aim at capturing the extent to which MNEs expect to benefit from localised innovative dynamism and knowledge spillovers from indigenous firms (Mariotti, Piscitello \& Elia, 2010; McCann and Mudambi 2005). Moreover, to go beyond formal innovation, we introduce the Social Filter Index (Crescenzi et al., 2007 and 2012; Crescenzi and Rodríguez-Pose 2011), which is an indicator resulting from the combination of a broader set of structural socio-economic characteristics, playing a crucial role in the definition of the profile of an innovation prone environment. This indicator is based on a number of characteristics of the local economy selected as measures of the structural pre-conditions for establishing fully functional regional systems of innovation and socio-institutional conditions favourable to the establishment of MNEs activities (Phelps et al., 2003; Phelps and Waley, 2004; Fuller, 2005). Under the constraint of the limited availability of regional data for the EU 25 regions, the Social Filter includes two major domains: 1) educational achievements corresponding to human capital accumulation both in the regional population and among employed people (Malecki 1997; Marrocu and Paci, 2012) and 2) productive employment of human resources measured by the percentage of the labour force employed in agriculture and the long-term component of unemployment (Fagerberg et 
al.,1997; Gordon 2001). These two domains, when assessed simultaneously, generate a unique socioeconomic profile that fosters (hinders) the innovative capacity of each region. ${ }^{6}$

We expect that both Patent Intensity and the Social Filter positively influence investments aimed at seeking strategic assets. According to the existing literature this scope is crucial for EMNEs investing in the EU.

3) Efficiency seeking motivation. Regional unemployment is a proxy of the labour market conditions in terms of the excess of labour supply over demand (Py and Hatem, 2009). The lack of regional data about labour costs/wages precludes a direct control of the differential across regions, although in the EU a large part of these differences is represented by national differences and country-level effects control for them. In the case of EMNEs investing in the EU, we do not expect efficiency seeking motivation playing a key role.

4) Regional agglomeration of foreign investments. In order to capture the impact of the agglomeration of foreign investments in the regional economy the model includes three indicators aimed at catching the tendency of foreign investments to 'cluster' in a limited set of locations (in line with Mariotti and Piscitello 1995; Guimaraes, et al., 2000; Head and Mayer 2004; Dunning, 2009). The impact of pre-existing investments on the location of MNCs is captured by means of the total number of pre-existing foreign investments in the region. Moreover, the model also accounts for the 'attractiveness' of the total number of investments in the same sector of activity as the new investment ${ }^{7}$ and the number of investments pursuing the same function. ${ }^{8}$ Due to their little previous experience in the EU, EMNEs are expected to strongly rely on the informational spillovers deriving from the concentration of similar firms in both functional and sectorial terms.

\footnotetext{
${ }^{6}$ The structural variables for each dimension (Table A-2) are combined by means of Principal Component Analysis on the basis of the scores presented in Table A-2.

${ }^{7}$ Investments are classified in 39 sectors by fDi Markets.

${ }^{8}$ As explained in 3.2, the dataset provides a classification of the investments in 18 functions.
} 


\section{EMPIRICAL RESULTS}

This section includes the results of the Nested Logit estimation: sub-section 4.1 presents the regional-level analysis (referring to the upper part of Tables 2 and 3) that assesses the relative importance of market, strategic asset and efficiency seeking strategies and of the agglomeration factors. The significance of these location determinants is estimated for all investors (Column 1), for investors from within the EU (Column 2: EU), from North America (Column 3: NA) and from emerging economies (Column 4: EMNE). The comparison of the relative importance of the different drivers of MNEs location decisions sheds light on the different strategies adopted by these firms depending on their origin.

In the second sub-section (4.2) - which makes reference to the lower part of the Tables 2 and 3- the weight ascribed by the investors to the regional drivers with respect to the national common factors is assessed through the analysis of the Inclusive Values (IV) or dissimilarity parameters. Furthermore in order to test how MNEs strategies differ across productionoriented and non-production functions the location drivers are assessed for all investments (Table 2) first and then separately for the sub-sample of non-production investments in order to capture the distinctive location patterns of possibly more knowledge-intensive and sophisticated functions (Tables 3).

All the explanatory variables are introduced in the regressions with a one-year lag in order to minimise the impact of simultaneity between the investment decisions and local economic conditions (Spies, 2010). Besides, in order to resolve the problem of different accounting units, explanatory variables are generally expressed for each region as a percentage of the respective GDP or population. When interpreting the results it is important to bear in mind that the focus is mainly on the sign and significance of the coefficients, rather than on the size of specific point estimates. In addition the results should not be interpreted in terms of 
causality relations. Finally, it is worth reminding that the 'country-level' nested structure allows us to control for 'unobserved' factors that regions belonging to the same country have in common, such as the 'macro' institutional framework, rule of law, tax rates and fiscal regimes. In a robustness check discussed in section 4.2 we also test an alternative nest structure for the EU regions comparing the regional belonging to the EU10 vs. EU15 ${ }^{9}$ in order to assess the relevance of the diversity of the business environment between Central and Eastern European countries (EU10) and the EU most advanced economies (EU15) as the relevant 'nest' in the regional allocation of foreign investments.

\subsection{The location determinants of EMNEs and AMNEs in the European regions}

In this section our attention focuses on how the regional level location determinants (reported in the upper part of Tables 2 and 3) impact on the regional probability of attracting MNEs investments.

\section{[Tables $2 \& 3$ about here]}

When looking at all investments in the EU regions, regional GDP per capita exerts a negative and significant influence on the probability of attracting FDIs (Table 2, Column 1), suggesting that traditional market seeking motivations do not play a key role in attracting investments in Europe and that a de-concentration of investments away from core wealthy regions (i.e. those with relatively higher GDP per capita) is taking place. However, this somewhat unexpected result - contrasting with existing literature (e.g. Head and Mayer, 2004 and Loore and Guisinger, 1995) - changes when FDIs are differentiated by country of origin.

\footnotetext{
${ }^{9}$ EU 10 includes: Cyprus, Czech Republic, Estonia, Hungry Lithuania, Latvia, Malta Poland, Slovenia, Slovakia. EU15 includes Austria, Belgium, Denmark, Finland, France, Germany, Greece, Ireland, Italy, Luxembourg, Netherlands, Portugal, Spain, Sweden, and United Kingdom. For the sake of brevity, these results are not included in the paper but they are available from the authors.
} 
In fact, the negative and significant impact is confirmed only for intra-EU investments (Column 2), while non-EU FDIs, from both North America (Column 3) and from emerging countries (Column 4) are attracted by regions with high per capita GDP. This difference in the behaviour of MNEs is motivated by the fact that EU companies do not need to undertake market-seeking investments within the EU: in the common market they do not face trade barriers and transaction costs are low due to the geographic and cultural proximity among countries. On the contrary, both for NA multinationals and for EMNEs the market seeking motivation is strong and driven by the aim to be present in the largest EU markets. As a consequence, in this case a clear behavioural difference emerges between intra-EU and extraEU investments (both from NA and emerging countries) as a result of their diverse, marketseeking strategies. Further evidence in this regard is shown in Table 3 where the empirical analysis focuses on more knowledge-intensive functions by excluding purely productionoriented investments. In this case, the market seeking motivation is only confirmed for NA investments, while the coefficients become insignificant both for intra-EU investments and for EMNEs, which, as discussed below, seem to be driven more by strategic asset seeking motivations (Table 3, Columns 2, 3 and 4).

When considering strategic asset seeking motivations, the empirical results unveil additional behavioural heterogeneity according to the origin of the investments. In Column 1 (Table 2), regional Patent intensity has a positive and statistically significant impact on the probability of attracting all MNEs, confirming the importance of the availability of technological competences and resources in the location decisions of multinational companies. However, when the sample is disaggregated by the origin of the investing companies, this relationship is confirmed only for investments generated from within the EU and from North America (Table 2, Columns 2 and 3). In the case of EMNEs, patent intensity exerts a positive and significant influence only on investments in the more sophisticated (non-production) 
functions (Table 3, Column 4). This evidence is particularly important because it confirms the diversified internationalisation strategy of EMNEs that invest in Europe to seek both markets and high-value strategic assets, the latter involving functions such as $R \& D$, design and development (Amighini et al., 2013).

The analysis of the role of broad socio-economic factors supporting innovation sheds additional light on strategic asset seeking behaviours. In Table 2 the Social Filter - our proxy for 'soft' innovation factors and socio-economic innovation proneness - is positive and significant only for intra-EU investments. Extra-EU companies are less likely to respond to 'soft' innovation factors given their lack of socio-cultural and cognitive proximity (Boschma, 2005) and their more limited degree of local embeddedness (Granovetter, 1985; Phelps et al., 2003; Phelps and Waley, 2004; Fuller, 2005). This result is further reinforced when the sample is restricted to non-production functions (HQ/R\&D/SALE/DIST) (Table 3). In addition, it is worth noticing that the Social Filter becomes positive and significant for North American companies when - in our robustness check - the two macro-aggregated groups EU10 and EU15 replace the country-level nests. This suggests that for North American companies the importance of 'soft' factors is fully accounted for by the country-level characteristics: regional social-filters are not significant when common characteristics at the national level are fully controlled for (as in Table 3) and only emerge when 'broader' controls (EU15 vs. EU 10) are included.

Regional unemployment - our proxy for efficiency-seeking motivations - does not seem to play a relevant role as an explanatory factor for the location of MNEs. This variable is never significant in the aggregated model (Table 2) but it turns out positive and significant in nonproduction-oriented functions (Table 3, Column 1) when investments are not separated by country of origin while it remains insignificant for all origins (Columns 2 to 4). This suggests a strong 'composition effect': when all non-manufacturing investments are assessed together 
efficiency seeking motivations seem to be relevant explanations for FDI in the EU. However, once origin-country heterogeneity is accounted for by means of separate sub-samples, their impact disappears. Column 1 in Table 3 shows that investments in non-production and supposedly more knowledge-intensive functions are sensitive to a number of different drivers: market seeking (GDP per capita); strategic asset seeking (Patent per capita and Social Filter) and efficiency seeking (Regional unemployment). However, while all other factors remain significant for one or more groups of countries (suggesting that the area of origin does influence MNEs preferences in their regard) the same is not true for regional unemployment. In line with previous research (e.g. Disdier and Mayer 2004) these results suggest that efficiency-seeking motives should be assessed on a case-by-case basis being so hard to draw any 'general' conclusion on their role. In addition, in the very nationally centralised EU labour markets, regions might play a relatively minor role in this regard: as a matter of facts in our robustness check - where national 'controls' are replaced by broader EU15 vs. EU 10 nests - in line with our results for market seeking motives intra-EU investments favour locations where the supply of labour is more abundant and potentially cheaper (i.e. those with a higher unemployment rate) while North American investments prefer 'core' low unemployment locations. In other words, if NA MNEs decide to invest in the EU, they rather seek strategic assets than higher efficiency (lower costs) locations. The same does not apply to EU MNEs that, when investing within the EU, look for 'cheaper' locations.

As discussed in Section 2, the process of agglomeration of MNEs investments is an additional important explanation of their location behaviour. In that regard Table 2 shows a negative, although only marginally significant, coefficient for intra-EU investments (Column 2), confirming a process of de-concentration of EU investments towards less congested regions, in line with the findings discussed above on GDP per capita and regional unemployment. Then considering the two other indicators of agglomeration - the cumulative number of pre- 
existing investments in the same sector and in the same function in the region - a completely different story emerges. Both agglomeration proxies exert a significant and positive influence on the location of all investments. The cumulative nature of investment location choices confirms the expected role of specialised agglomeration economies and informational spillovers (Guimaraes et al.,, 2000; Head and Mayer, 2004; Spies, 2010; Belderbos et al. 2011). Location decisions are driven by two agglomeration forces: (i) the search for 'vertical' interactions when investments are attracted by the presence of other investments in the same sector but in other functions and (ii) 'horizontal' spillovers, such as labour market specialisation and supply of specialised services and infrastructures, when they agglomerate on the basis of the same function across sector. It is worth noticing that the agglomeration effect for all sets of functions is consistent for all MNEs notwithstanding their origin while the sectorial agglomeration becomes insignificant for EMNEs investing in non-production functions (Tables 3, Columns 4). This is a new original finding about the location behaviour of EMNEs: given the high uncertainty characterising their early explorations in the EU regions, multinationals from emerging countries choose to locate in regions specialised in the same sets of functions as their foreign investment, searching for informational spillovers and agglomeration economies when undertaking strategic asset-seeking investments in higher value-added functions.

\subsection{Regional vs. national drivers}

Turning our attention to the lower sections of Tables 2 and 3 the analysis of the Inclusive Values (IV) or dissimilarity parameters assesses the weight ascribed by the investors to regional level drivers vs. national common factors. This analysis contributes to undertake a much needed fine-grained understanding of the location behaviour of MNEs (Beugelsdijk and Mudambi, 2013; Iammarino and McCann, 2013). The interpretation of the values assumed by 
the dissimilarity parameters allows us to shed new light on the relative importance of subnational spatial heterogeneity against national factors.

Dissimilarity parameters measure the level of independence of the alternatives in each nest (i.e. country in Tables 2 and 3 and group of countries in our EU10 vs. EU15 robustness check) with respect to the unobserved portions of utility: the closer a parameter is to 1 , the greater is the independence (lower correlation) between the alternatives (regions) in the same nest (country and group of countries). Therefore, if the IVs are close to 1 the regional drivers have a stronger role than the national common factors in attracting MNEs, while if they are close to 0 the national drivers prevail. ${ }^{10}$ It is worth remembering that the national common factors also account for the impact of different institutional conditions, quality of infrastructure, business climate, political factors at the country level that remain hard to capture explicitly by means of quantitative indicators.

In the econometric tests undertaken, the fitted models in general behave well and the dissimilarity parameters are mostly within the 0-1 ranges. The LR statistics confirm the validity of the nested structures presented in Tables 2 e 3 and support the robustness of our empirical model. However, significant differences emerge in the ways in which MNEs balance national and regional drivers in their investment strategies depending on their origin and on the functions undertaken.

In what follows, our discussion in based on the IVs in Table 3 only, given that they do not differ substantially from IVs in Table 2. The analysis of the inclusive values for intra-EU investments shows that country-level considerations still play an important role: inclusive values are all statistically significant and far from 1 (Column 2 in Table 3). The location decisions in regions belonging to the same country are closely correlated and driven by

\footnotetext{
${ }^{10}$ The Random Utility model restricts dissimilarity parameters to a range between 0 and 1 and values outside this range mean that while the model is mathematically correct, the fitted model is inconsistent with the randomutility theory (Cameron \& Trivedi 2008).
} 
stronger common national factors as opposed to investments in a different country. Investments in the UK represent an exception because they are strongly guided by subnational drivers, as shown by the relatively higher inclusive values and reflecting the unique role of some specific investment hubs, such as London and the Southwest.

Investments from North America (Column 3) are also sensitive to country-level common factors (as confirmed by the LR Test and the significant inclusive values) but regional-level considerations play a more important role than for intra-EU investments because the values of all IVs are generally higher.

When it comes to EMNEs the picture is again different. LR Test confirms the significance of country-level nests (Column 4). Furthermore, the analysis of the parameters associated to individual countries shows that the IVs for the UK, Germany and France are significant and relatively large and IVs for The Netherlands and Italy are also significant but smaller. On the contrary, many other IVs are either marginally significant or insignificant. This suggests that EMNEs attach great importance to both the regional and national common features of those countries that have historically received the larger shares of their investments and with the closer 'cultural' proximity (these same emerging countries have often hosted investments from European countries). EMNEs do not seem to take into account any additional common factor (on top of the regional drivers discussed in the previous section) when taking their locations decisions outside the UK, Germany, France and to a less extent The Netherland and Italy.

As said before, we have also tested an alternative nest structure for the MNEs' investments, the EU15 vs. EU10 being most 'natural' in the EU context to take into account the differences between the most advanced countries in the EU and the most recent entrants. While the key results concerning the regional drivers are qualitatively confirmed, the LR test suggests that the EU10 vs. EU15 subdivision is not relevant for EMNEs location choices, confirming the 
country-level as the key node for they location decisions. Conversely, for intra-EU and NA investments the EU-10 vs. EU-15 dichotomy is relevant: investment in the 'old' Europe brings a premium in terms institutional context and skill sophistication that remains difficult to 'read' for EMNEs due to larger cultural distance.

\section{CONCLUSIONS}

This paper contributes to the current conceptual debate in both Economic Geography and International Business Studies on the nature and strategies of MNEs from emerging countries. In particular the paper fills a very relevant gap in the existing literature by exploring whether EMNEs differ from AMNEs in their location decisions at the national and sub-national levels. Table 4 summarises the main empirical findings of the paper.

\section{[Table 4 about here]}

The first key result is that MNEs from countries at different technological and developmental stages do follow a diverse set of sub-national investment motives. The wealthy markets of the 'core' EU regions attract investments from extra-EU MNEs - both from emerging countries and from North America - while intra-EU investments tend to target less affluent and less congested regions. Coherently with this evidence of intra-EU de-concentration, the spatial agglomeration of pre-existing foreign investments in the same region appears to discourage FDI from within the Union while EMNEs and AMNEs are not influenced by the agglomeration of investments per se: what matters for all MNEs (including EMNEs) are functional and sectorial agglomeration forces. Conversely, efficiency seeking motives are generally less important and largely captured by national effects.

The second key result is that strategic asset seeking motives are central to the understanding of the specificities of EMNEs' spatial behaviour in comparison to all other MNEs. EMNEs seek technological competences (i.e. patent intensity) only when they invest in higher value 
added functions. However, 'soft' regional innovation conditions (i.e. the Social Filter) are never significant attraction factors for EMNEs. The large innovation and technological gap still prevents EMNEs from fully taking advantage of an innovation-prone regional context. This implies that EMNEs prove still rather inexperienced when undertaking strategic asset seeking investments because they might still lack adequate absorptive capacity.

Third, the paper contributes to the debate on the relative importance of regional drivers as opposed to national location factors (Beugelsdijk and Mudambi, 2013; Iammarino and McCann, 2013). The analysis shows that EMNEs attach great importance to both the regional and national location factors. In the UK, France, Germany, The Netherlands and Italy regional factors are prevalent while their location choices in all other EU countries are driven more by national common factors.

The paper has a number of limitations. Even if regional characteristics are introduced in the empirical analysis with a one-year-lag to minimise the impact of the potential simultaneity between local conditions and foreign investments, the results should be interpreted as descriptive without any presumption of causality. In addition, the investment dataset although robust relative to other similar datasets - is limited to greenfield investments with no information on other typologies of FDI (e.g. mergers and acquisitions) or on non-equity forms of internationalisation. Moreover, the dataset does not allow including any 'parent company' controls for repeated investments by the same firm in different locations. These investments are certainly not independent but the current dataset does not allow reconstructing the ownership structure of MNEs, and capturing the linkages among investments. Some of these limitations will be addressed in our future research by extending the existing FDI database to include mergers and acquisitions as well as undertaking an empirical analysis at the level of the investing firm. 
However, having acknowledged the limitations mentioned above, our results could still provide some relevant insights for national and regional policy-makers. In a context of limited capital availability in the aftermath of a major economic crisis the attraction of foreign investment is crucially important to re-launch national and regional economic growth. In this context, EMNEs can play a key role: the relatively more solid performance of their domestic markets and their strong average capitalisation make them ideal investors to be targeted by national and regional attraction policies and incentive packages. As a consequence, understanding the specificities of their location strategies remains of paramount importance. From our empirical analysis it clearly appears that these new actors are not moved by efficiency-seeking motives. Their interest for large markets - that cannot easily be influenced by public policies - is coupled by two other 'attraction' factors: strategic assets and functional and sectorial agglomeration economies. Moreover, their spatial behaviour is different from other MNEs in particular when it comes to the most sophisticated knowledge intensive functions that also display the strongest potential for spillovers and growth in recipient economies.

Policymakers can play a multiple and diversified role. In order to leverage strategic asset seeking motives policymakers should not only reinforce national and regional technological capabilities but also support the development of 'institutional bridges' able to facilitate EMNEs in their understanding of 'soft' innovation drivers. Helping EMNEs to capture the advantages of the rich national and regional innovation system landscape in the EU might be the key to attract their investments in the most 'valuable' functions. In this regard the support of connections with local firms (e.g. joint ventures but also non-equity alliances) and universities might be a possible policy tool to facilitate connectivity into local innovation systems. This would also generate opportunities for advanced host countries' managers and entrepreneurs to learn from new investors, bridging the cultural and market distance with 
emerging economies. This for example was sought after by Costa Rica's investment promotion organisation CINDE (Coalition of Development Initiatives) in its selective strategy to attract Intel and other foreign investors (Blyde et al., 2014). The establishment of networking opportunities involving both new investors and host countries' local actors is key in order to reduce the risk of a "take and leave" attitude of EMNEs (Giuliani et al., 2014) as and as well as the opportunistic acquisition of cheap assets with respect to technology and other strategic assets, which is diffusely feared in European countries. ${ }^{11}$ Policymakers would benefit from a better understanding of EMNE behaviour in Europe in order to minimise predatory investment and attract investments contributing to the local economy.

In addition, the possibility to leverage functional and sectorial agglomerations is premised on a careful diagnosis of the national and regional economy, in order to make these agglomeration benefits apparent to EMNEs (and other investors as well). In this regard, policymakers should facilitate the development of functional and sectorial integrated systems comprising both domestic and foreign firms. Finally, our results highlight that both national and regional governments and policymakers are relevant to EMNEs, suggesting that coordination and joint action among different government levels is of primary importance.

\footnotetext{
${ }^{11}$ See for instance a recent article in the Financial Times http://www.ft.com/cms/s/2/53b7a268-44a6-11e4-ab0c$\underline{00144 f e a b d c 0 . h t m l}$, accessed 17 February 2015.
} 


\section{References}

Alcacer, J., Delgado, M. 2013, Spatial organization of firms and location choices through the value chain. HBS Working Paper 13-025.

Alfaro, L. and Xiaoyang Chen M. 2014, The global agglomeration of multinational firms, Journal of International Economics 94, 263-276

Amighini A., Cozza C.,.Rabellotti R. and Sanfilippo M., 2014, Chinese Outward FDI: What Can Be Done with Firm-level Data?, China and the World Economy, 22, 6: 44-63.

Amighini A, Rabellotti R., Sanfilippo M., 2013, Do Chinese State-Owned and private Enterprises Differ in their Internationalization Strategies?, China Economic Review, $27,312-325$.

Ali-Yrkkö J., Rouvinen P., Seppälä T., Ylä-Anttila P., 2011, Who Captures Value in Global Supply Chains? Case Nokia N95 Smartphone, ETLA Discussion Papers No.1240, 28 Feb. 2011.

Basile, R., Castellani, D., \& Zanfei, A., 2008, Location choices of multinational firms in Europe: The role of EU cohesion policy. Journal of International Economics, 74(2), 328340.

Belderbos R, Carree MA. 2002. The location of Japanese investment in China: agglomeration effect, Keiretsu and firm heterogeneity. Journal of Japanese and International Economies 16: $194-211$.

Belderbos, R., Olffen, W. V., \& Zou, J. 2011. Generic and specific social learning mechanisms in foreign entry location choice. Strategic Management Journal, 32(12), 1309-1330.

Bertoni, F., Elia, S., \& Rabbiosi, L. 2013. Outward FDI from the BRICS: Trends and patters of acquisitions in advanced countries. In M. A. Marinov, \& S. T. Marinova (Eds.), Emerging economies and firms in the global crisis. Basingstoke: Palgrave Macmillan. 
Beugelsdijk, S., \& Mudambi, R. 2013. MNEs as border-crossing multi-location enterprises: The role of discontinuities in geographic space. Journal of International Business Studies, 44(5), 413-426.

Blyde J., Pietrobelli C. and Volpe C., 2014, “A World of Possibilities: Internationalization for Productive Development“, G. Crespi, E. Fernández-Arias and E.H. Stein (Eds.) Rethinking Productive Development: Sound Policies and Institutions for Economic Transformation, Palgrave for Inter-American Development Bank.

Boschma R. A. 2005 "Proximity and innovation: a critical assessment", Regional Studies 39 (1), 1-14.

Buckley, P. J., Clegg, J., Cross, A. R., Liu, X., Voss, H., \& Zheng, P. 2007. The determinants of Chinese outward foreign direct investment. Journal of International Business Studies, 38 (4), 499- 518.

Cameron A.C., Trivedi P.K. 1998. Regression Analysis of Count Data, Econometric Society Monograph No.30, Cambridge University Press.

Cantwell, J., \& Piscitello, L. 1999. The emergence of corporate international networks for the accumulation of dispersed technological competences. MIR: Management International Review, 123-147.

Castellani, D., and Pieri, F. 2013. R\&D off shoring and the productivity growth of European regions. Research Policy, 42(9), 1581-1594.

Crescenzi, R., Rodríguez-Pose A. and Storper M. 2007. "The territorial dynamics of innovation: a Europe-United States Comparative Analysis", The Journal of Economic Geography, 7, 6: 673-709.

Crescenzi R. and Rodríguez-Pose A. 2011. "Innovation and regional growth in the European Union”, Springer-Verlag, Berlin and New York 
Crescenzi R., Rodríguez-Pose A. \& Storper M. 2012. "The territorial dynamics of innovation in China and India”, Journal of Economic Geography, 12, 1055-1085.

Crescenzi R., Pietrobelli C., and Rabellotti R., 2014, "Innovation drivers, value chains and the geography of multinational corporations in Europe", Journal of Economic Geography 14, 1053-1086.

Cuervo-Cazurra A. and Ramamurti R. (eds) (2014) Understanding Multinationals from Emerging Markets Cambridge University Press: Cambridge, UK

Defever, D. (2006) Functional fragmentation and the location of multinationals firms in the enlarged Europe. Regional Science and Urban Economics, 36: 658-677.

Devereux, M., Griffith, R., Simpson, H., 2007. Firm location decisions, regional grants and agglomeration externalities. Journal of Public Economics 91, 413-435.

Dimitratos, P, Liouka, J, and Young, S .2009. "Regional Location of Multinational Corporation Subsidiaries and Economic Development Contribution: Evidence from the UK.” Journal of World Business, 44 (2): 180-191.

Disdier, A. C., Mayer, T. 2004 How different is Eastern Europe? Structure and determinants of location choices by French firms in Eastern and Western Europe. Journal of Comparative Economics, 32: 280-296.

Dunning J. H., 1977 Trade, location of economic activity and the multinational enterprise: a search for an eclectic approach, in B. Ohlin, P.O. Hesselborn and P.M. Wijkman (eds.), The international allocation of economic activity, London, Macmillan: 19-51.

Dunning, J. H. 1998. Globalization and the new geography of foreign direct investment. Oxford Development Studies, 26(1), 47-69.

Dunning, J. H. 2009. Location and the multinational enterprise: A neglected factor?, Journal of international business studies, 40(1), 5-19. 
Duysters, G., Jacob, J., Lemmens, C., \& Jintian, Y. 2009. Internationalization and technological catching up of emerging multinationals: A comparative case study of China's Haier Group. Industrial and Corporate Change, 18(2), 325-349.

Fagerberg J., Verspagen, B., and Caniels, M. 1997. "Technology, growth and unemployment across European Regions”. Regional Studies, (31:5), pp. 457-466.

Flores, R. G., \& Aguilera, R. V. 2007. Globalization and location choice: an analysis of US multinational firms in 1980 and 2000. Journal of International Business Studies, 38(7), 1187-1210.

Fuller C., 2005. Corporate Repeat Investment and Regional Institutional Capacity. The Case of After-care Services in Wales. European Urban and Regional Studies 12, 5-21.

Gammeltoft, P. 2008. Emerging multinationals: outward FDI from the BRICS countries. International Journal of Technology and Globalisation, 4(1), 5-22.

Goldstein, A. (2009). Multinational Companies from Emerging Economies. Palgrave Macmillan.

Gordon I.R. 2001. Unemployment and spatial labour markets: strong adjustment and persistent concentration in R. Martin and P. Morrison (eds.) Geographies of Labour Market Inequality, Routledge, London.

Gereffi G., Humphrey J. and Sturgeon T. 2005. "The governance of global value chains", Review of International Political Economy, 12 (1): 78-104.

Giuliani E., Gorgoni S., Guenther C. and Rabellotti R., 2014, "Emerging-market MNEs investing in Europe. A typology of subsidiary global-local connections”, International Business Review, 23: 680-691.

Granovetter, M., 1985. "Economic action and social structure: the problem of embeddedness", American Journal of Sociology, 91(3), 481-510. 
Guimarães P. Figueiredo O. and Woodward D. 2000. "Agglomeration and the Location of Foreign Direct Investment in Portugal”, Journal of Urban Economics, 47, 1: 115-135.

Jordaan J.A. 2009. Foreign Direct Investment, Agglomeration and Externalities, Ashgate, Farnham.

Head, K. and Mayer T. 2004. "Market potential and the location of Japanese investments in the European Union." Review of Economics and Statistics 86, 4: 949-972.

Head, C.K., Ries J.C. and D. L. Swenson 1995. "Agglomeration benefits and location choice: Evidence from Japanese manufacturing investment in the United States." Journal of International Economics 38, 3-4: 223-247.

Head, C.K., J.C. Ries and D. L. Swenson 1999. "Attracting foreign manufacturing: Investment promotion and agglomeration”, Regional Science and Urban Economics, 29, $197-218$

Kraemer K.L., Linden G., and Dedrick J, 2011, "Capturing Value in Global Networks: Apple’s iPad and iPhone”, University of California, Irvine, mimeo, July 2011

Iammarino S. and McCann P. 2013, Multinationals and Economic Geography, Edward Elgar, Cheltenham (UK) and Northampton (USA)

Kedia, B., Gaffney, N., \& Clampit, J. 2012. EMNEs and Knowledge-seeking FDI. Management International Review, 52(2), 155-173.

Kraemer, K., Linden, G., \& Dedrick, J. 2011. Capturing value in Global Networks: Apple's iPad and iPhone. University of California, Irvine, University of California, Berkeley, y Syracuse University, NY. http://pcic. merage. uci. edu/papers/2011/value_iPad_iPhone. $p d f$.

Kumar, K., \& McLeod, M. G. 1981. Multinationals from developing countries. Free Press.

Lall, S., \& Chen, E. 1983. The new multinationals: The spread of third world enterprises. Chichester: Wiley. 
Loree, D. W., \& Guisinger, S. E. 1995. Policy and non-policy determinants of US equity foreign direct investment. Journal of International Business Studies, 26, 2, 281-299.

Makino, S., Lau, C.M., \& Yeh, R.S. 2002. Asset- Exploitation versus Asset Seeking: Implication for Location Choice of Foreign Direct Investment from Newly Industrialized Economies. Journal of International Business Studies, 33 (3), 403-421.

Malecki E. 1997. Technology and Economic Development: The Dynamics of Local, Regional and National Competitiveness, 2nd edition Addison Wesley Longman, London.

Mariotti, S., Piscitello, L. 1995. Information costs and location of FDIs within the host country: empirical evidence from Italy. Journal of International Business Studies, 26: 815841.

Mariotti. S., Piscitello, L. Elia, S., 2010. Spatial agglomeration of multinational enterprises: the role of information externalities and knowledge spillovers, Journal of Economic Geography, 10 (4): 519-538

Marrocu E. and Paci R., 2012. Education or Creativity: What Matters Most for Economic Performance?, Economic Geography, 88(4): 369-401.

Mathews, J. A. 2006. Dragon multinationals: New players in 21st century globalization. Asia Pacific journal of management, 23(1), 5-27.

McCann, P. and R. Mudambi, 2005. Analytical differences in the economies of geography: the case of the multinational firm. Environment and Planning A, 37: 1857-1876.

McFadden, D. L. 1984. Econometric analysis of qualitative response models. In: Griliches, Zvi, Intriligator, Michael D. (Eds.), Handbook of Econometrics, Vol.2. Amsterdam, Elsevier/North-Holland: 1396-1457.

Narula, R. 2010. "Much ado about nothing, or sirens of a brave new world?: MNE activity from developing countries and its significance for development”. OECD Background paper for the Perspectives on Global Development 2010, Paris:OECD. 
Phelps N. A., MacKinnon D., Stone I. and Braidford P., 2003. Embedding the multinationals? Institutions and the development of overseas manufacturing affiliates in Wales and North East England, Regional Studies 37, 27-40.

Phelps N. A., Waley P. 2004, Capital Versus the Districts: A Tale of One Multinational Company's Attempt to Disembed Itself, Economic Geography 80, 191-215.

Pietrobelli C. and Rabellotti R. 2007. Upgrading to Compete. Clusters and Value Chains in Latin America, Cambridge Ma.: Harvard University Press.

Pietrobelli C., Rabellotti R and Sanfilippo M. 2011 The "Marco Polo" effect: Chinese FDI in Italy, Int. J. Technological Learning, Innovation and Development, , 4(4), 277-291.

Py L. and Hantem F. 2009. Internationalisation et Localisation des Services: une Analyse Sectorielle et Fonctionelle Appliquee aux Firmes Multinationales en Europe, Economie et Statistique, 426, 67-95

Ramamurti, R., \& Singh, J.V. 2009. Emerging Multinationals in emerging markets. Cambridge UK: Cambridge University Press.

Ramamurti, R. 2012. What is really different about emerging market multinationals? Global Strategy Journal, 2: 41-47.

Ramasamy, B., Yeung M. and Laforet S., 2012, “China's outward foreign direct investment: Location choice and firm ownership,” Journal of World Business, Vol. 47, pp. 17-25

Rugman A., Verbeke A. and Yuan W. 2011. Re-conceptualizing Bartlett and Ghoshal's"Classification of National Subsidiary Roles in the Multinational Enterprise", Journal of Management Studies 48(2): 253-277.

Spies J. 2010. Network and border effects: Where do foreign multinationals locate in Germany?, Regional Science and Urban Economics, 40, 20-32 
Sutherland, D., and Anderson, J. 2014. The Pitfalls of Using Foreign Direct Investment Data to Measure Chinese Multinational Enterprise Activity. Forthcoming in The China Quarterly, 1-28.

UNCTAD. 2014. World Investment Report 2014: Investing in the SDGs: An Action Plan. Geneva: United Nations Conference on Trade and Development. 
Table 1 - Number of new investments in EU27: Countries of origin

\begin{tabular}{|c|c|c|c|}
\hline Country Group & $\begin{array}{c}\text { Country of } \\
\text { origin }\end{array}$ & $\begin{array}{c}\text { \# of new } \\
\text { investments }\end{array}$ & $\begin{array}{l}\% \text { of } \\
\text { total }\end{array}$ \\
\hline \multirow{26}{*}{ EU 25} & & 13100 & 59.55 \\
\hline & Germany & 3090 & 14.05 \\
\hline & $U K$ & 1934 & 8.79 \\
\hline & France & 1510 & 6.86 \\
\hline & Austria & 882 & 4.01 \\
\hline & Netherlands & 865 & 3.93 \\
\hline & Sweden & 779 & 3.54 \\
\hline & Italy & 764 & 3.47 \\
\hline & Spain & 691 & 3.14 \\
\hline & Belgium & 427 & 1.94 \\
\hline & Finland & 425 & 1.93 \\
\hline & Denmark & 390 & 1.77 \\
\hline & Ireland & 253 & 1.15 \\
\hline & Greece & 231 & 1.05 \\
\hline & Lithuania & 126 & 0.57 \\
\hline & Estonia & 109 & 0.50 \\
\hline & Luxembourg & 97 & 0.44 \\
\hline & Czech Republic & 93 & 0.42 \\
\hline & Slovenia & 93 & 0.42 \\
\hline & Hungary & 85 & 0.39 \\
\hline & Portugal & 83 & 0.38 \\
\hline & Poland & 78 & 0.35 \\
\hline & Latvia & 49 & 0,22 \\
\hline & Cyprus & 29 & 0.13 \\
\hline & Slovakia & 12 & 0.05 \\
\hline & Malta & 5 & 0.02 \\
\hline \multirow[t]{3}{*}{ EU 27} & & 13154 & 59.80 \\
\hline & Romania & 32 & 0.15 \\
\hline & Bulgaria & 22 & 0.10 \\
\hline \multirow[t]{3}{*}{ EU27 + 2} & & 13943 & 63,19 \\
\hline & Switzerland & 585 & 2.66 \\
\hline & Norway & 204 & 0.93 \\
\hline \multirow[t]{3}{*}{ North America } & & 5367 & 24.32 \\
\hline & USA & 4990 & 22.68 \\
\hline & Canada & 377 & 1.71 \\
\hline \multirow[t]{11}{*}{ Emerging countries } & & 1064 & 4.81 \\
\hline & India & 237 & 1.08 \\
\hline & China & 211 & 0.96 \\
\hline & Russia & 195 & 0.89 \\
\hline & Turkey & 127 & 0.58 \\
\hline & Hong Kong & 109 & 0.50 \\
\hline & Brazil & 44 & 0.20 \\
\hline & Мexico & 27 & 0.12 \\
\hline & South Africa & 34 & 0.15 \\
\hline & Thailand & 6 & 0.03 \\
\hline & Chile & 6 & 0.03 \\
\hline \multirow{3}{*}{ Others } & & 978 & 4.43 \\
\hline & Japan & 771 & 3.51 \\
\hline & Australia & 207 & 0.94 \\
\hline Rest of the World & & 713 & 3.23 \\
\hline Total & & 22065 & 100.00 \\
\hline
\end{tabular}

Source: Authors' elaboration on fDi Markets - 2003-2008 
Table 2 - Location of MNEs in the EU regions by origin

\begin{tabular}{|c|c|c|c|c|c|c|c|c|}
\hline & \multicolumn{2}{|c|}{ (1) } & \multicolumn{2}{|c|}{ (2) } & \multicolumn{2}{|c|}{ (3) } & \multicolumn{2}{|c|}{ (4) } \\
\hline VARIABLES & \multicolumn{2}{|c|}{ ALL } & \multicolumn{2}{|c|}{ Intra-EU } & \multicolumn{2}{|c|}{ North America } & \multicolumn{2}{|c|}{ EME } \\
\hline \multirow[t]{2}{*}{ Regional pc GDP } & \multicolumn{2}{|c|}{$-1.24 \mathrm{e}-06^{*}$} & \multicolumn{2}{|c|}{$-2.81 \mathrm{e}-06^{* * *}$} & \multicolumn{2}{|c|}{$6.44 \mathrm{e}-06 * * *$} & \multirow{2}{*}{\multicolumn{2}{|c|}{$\begin{array}{l}1.73 \mathrm{e}-05^{* *} \\
(8.43 \mathrm{e}-06)\end{array}$}} \\
\hline & \multicolumn{2}{|c|}{$(7.12 \mathrm{e}-07)$} & \multicolumn{2}{|c|}{$(7.47 \mathrm{e}-07)$} & \multicolumn{2}{|c|}{$(2.40 \mathrm{e}-06)$} & & \\
\hline \multirow[t]{2}{*}{ Patents per capita } & \multirow{2}{*}{\multicolumn{2}{|c|}{$\begin{array}{c}0.000208 * * * \\
(3.47 \mathrm{e}-05)\end{array}$}} & \multirow{2}{*}{\multicolumn{2}{|c|}{$\begin{array}{c}9.52 \mathrm{e}-05 * * * \\
(3.40 \mathrm{e}-05)\end{array}$}} & \multirow{2}{*}{\multicolumn{2}{|c|}{$\begin{array}{c}0.000408 * * * \\
(9.64 \mathrm{e}-05)\end{array}$}} & \multicolumn{2}{|c|}{ (8.43e-06) } \\
\hline & & & & & & & \multicolumn{2}{|c|}{$\begin{array}{c}0.000811 \\
(0.000659)\end{array}$} \\
\hline \multirow[t]{2}{*}{ Social filter } & \multicolumn{2}{|c|}{0.00800} & \multicolumn{2}{|c|}{$0.0143 * * *$} & \multicolumn{2}{|c|}{0.0211} & \multicolumn{2}{|c|}{0.0163} \\
\hline & $(0.005$ & $03)$ & $(0.005$ & & $(0.01$ & & $(0.0$ & 16) \\
\hline Region.unemploy & 0.000 & & 0.000 & & -0.00 & & -0.0 & 404 \\
\hline & $(0.000$ & 76) & $(0.001$ & & $(0.003$ & & $(0.0$ & 92) \\
\hline Total \# of & 0.0053 & $* * *$ & 0.0048 & $* * *$ & 0.0081 & & 0.007 & $1 * * *$ \\
\hline & $(0.000$ & 81) & $(0.000$ & & $(0.000$ & & $(0.00$ & 189) \\
\hline Total \# of & 0.014 & $* * *$ & 0.014 & & 0.011 & & 0.007 & $54 * *$ \\
\hline & $(0.000$ & 74) & $(0.000$ & & $(0.001)$ & & $(0.00$ & 326) \\
\hline Total \# of existing & -0.000 & 113 & -0.000 & & 0.000 & & 0.00 & 205 \\
\hline & $(0.000$ & 82) & $(0.000$ & & $(0.000$ & & $(0.00$ & 31) \\
\hline IV Parameters & & & & & & & & \\
\hline Austria & $0.0674 * * *$ & $(0.0080)$ & $0.0592 * * *$ & $(0.0088)$ & $0.0851 * * *$ & $(0.0187)$ & $0.133 * *$ & $(0.0667)$ \\
\hline Belgium & $0.132 * * *$ & $(0.0178)$ & $0.101^{* * *}$ & $(0.0154)$ & $0.311 * * *$ & $(0.0895)$ & 0.358 & $(0.243)$ \\
\hline CzechRep & $0.122 * * *$ & $(0.0144)$ & $0.104 * * *$ & $(0.0131)$ & $0.216^{* * *}$ & $(0.0518)$ & 0.470 & $(0.344)$ \\
\hline Germany & $0.225 * * *$ & $(0.0273)$ & $0.135^{* * *}$ & $(0.0165)$ & $0.498 * * *$ & $(0.0460)$ & $0.717 * * *$ & $(0.129)$ \\
\hline Spain & $0.150 * * *$ & $(0.0109)$ & $0.131 * * *$ & $(0.0117)$ & $0.283 * * *$ & $(0.0420)$ & $0.245 * *$ & $(0.0971)$ \\
\hline Finland & $0.0431 * * *$ & $(0.0086)$ & $0.0313 * * *$ & $(0.0075)$ & $-0.547 * * *$ & $(0.176)$ & -0.586 & $(0.359)$ \\
\hline France & $0.382 * * *$ & $(0.0180)$ & $0.351 * * *$ & $(0.0202)$ & $0.505 * * *$ & $(0.0347)$ & $0.269 * * *$ & $(0.0735)$ \\
\hline Greece & $0.0599 * * *$ & $(0.0095)$ & $0.0582 * * *$ & $(0.0105)$ & $0.0619 * * *$ & $(0.0201)$ & 0.00211 & $(104.7)$ \\
\hline Hungary & $0.197 * * *$ & $(0.0192)$ & $0.184 * * *$ & $(0.0200)$ & $0.152 * * *$ & $(0.0278)$ & 0.264 & $(0.167)$ \\
\hline Italy & $0.163 * * *$ & $(0.0127)$ & $0.146^{* * *}$ & $(0.0139)$ & $0.253 * * *$ & $(0.0351)$ & $0.330^{*}$ & $(0.187)$ \\
\hline Netherlands & $0.113 * * *$ & $(0.0115)$ & $0.0800 * * *$ & $(0.0109)$ & $0.171 * * *$ & $(0.0313)$ & 0.319 & $(0.258)$ \\
\hline Poland & $0.146^{* * *}$ & $(0.0172)$ & 0.222 & (0) & $0.177 * * *$ & $(0.0402)$ & 0.188 & $(0.122)$ \\
\hline Portugal & $0.0864 * * *$ & $(0.0134)$ & $0.0927 * * *$ & $(0.0176)$ & $0.116^{* * *}$ & $(0.0318)$ & $0.747 *$ & $(0.420)$ \\
\hline Slovakia & $0.138 * * *$ & $(0.0217)$ & $0.136^{* * *}$ & $(0.0263)$ & $0.183 * * *$ & $(0.0635)$ & 0.376 & $(0.581)$ \\
\hline UK & $0.666^{* * *}$ & $(0.0154)$ & $0.516^{* * *}$ & $(0.0189)$ & $0.902 * * *$ & $(0.0267)$ & $0.791 * * *$ & $(0.0932)$ \\
\hline Log likelihood & $-18413,131$ & & $-11657,179$ & & $-5777,207$ & & $\begin{array}{l}- \\
802,53648\end{array}$ & \\
\hline LR Test (IIA) & $1057.17 * * *$ & & $566.12 * * *$ & & $441.48 * * *$ & & $76.08 * * *$ & \\
\hline Observations & 571,740 & & 349,085 & & 195,249 & & 27,406 & \\
\hline
\end{tabular}

Standard errors in parentheses $* * * \mathrm{p}<0.01, * * \mathrm{p}<0.05, * \mathrm{p}<0.1$ 
Table 3 - Location of MNEs in the EU regions by origin: non-production oriented functions only (HQ/R\&D/SALES/DIS)

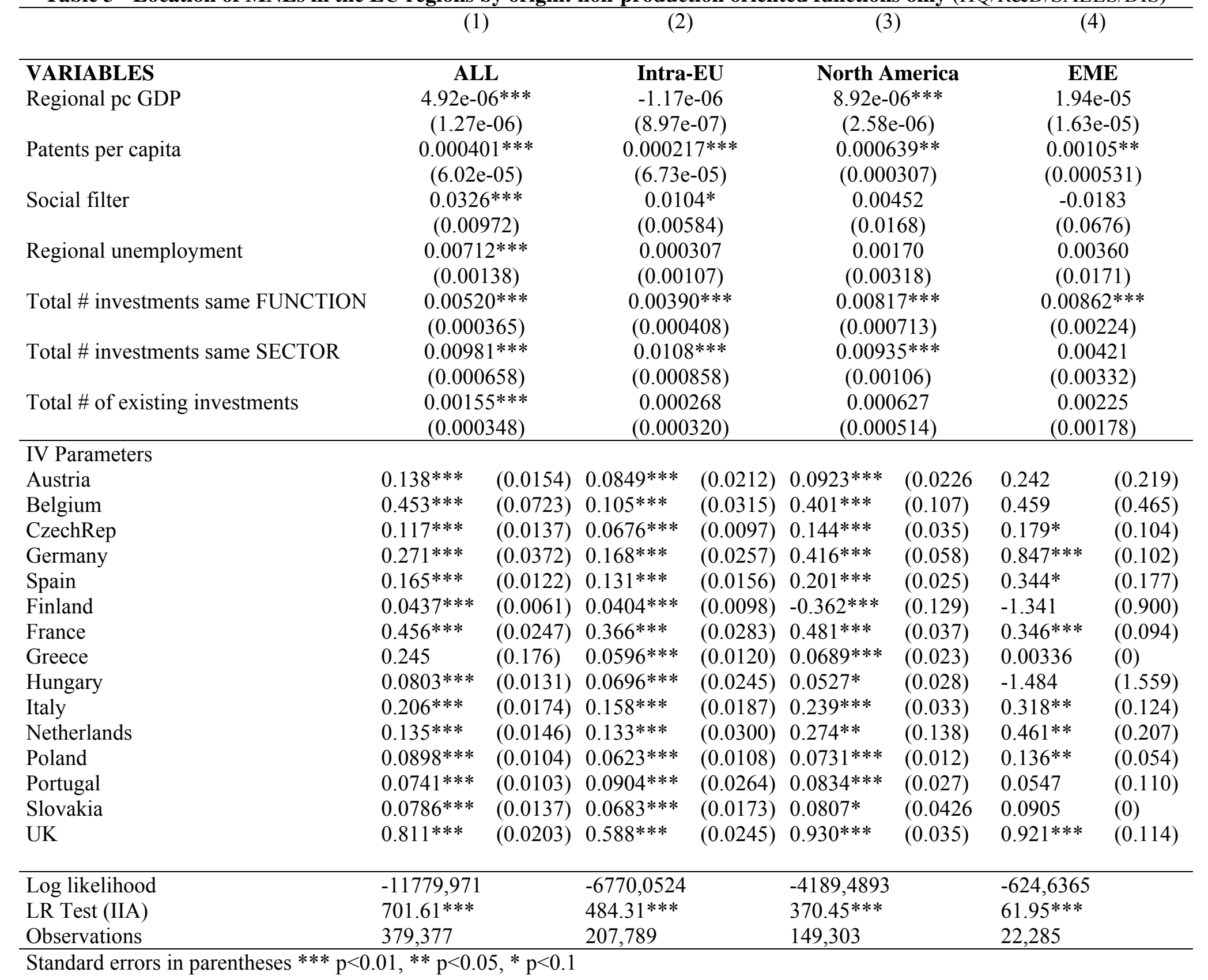


Table 4 - The location determinants of MNEs in the EU regions: A summary

\begin{tabular}{|c|c|c|c|}
\hline & \multicolumn{3}{|c|}{ Source of foreign investment } \\
\hline $\begin{array}{l}\text { Determinants of foreign } \\
\text { investments }\end{array}$ & $\mathbf{E U}$ & NA & EME \\
\hline Market-seeking* & $(-)$ & $(+)$ & $(+)$ \\
\hline \multicolumn{4}{|l|}{ Strategic asset-seeking* } \\
\hline \begin{tabular}{l|l} 
& Hard drivers (patents)
\end{tabular} & $(+)$ & $(+)$ & $\begin{array}{c}(+) \\
\text { Only for NON- } \\
\text { PRODUCTION FDI }\end{array}$ \\
\hline - Soft drivers & $(+)$ & $\begin{array}{c}(+) \\
\text { Only without full country } \\
\text { controls) }\end{array}$ & Never significant \\
\hline Efficiency-seeking* & $\begin{array}{l}(+) \\
\text { (Only without full } \\
\text { country controls) }\end{array}$ & $\begin{array}{c}(-) \\
\text { (Only without full } \\
\text { country controls) }\end{array}$ & Never significant \\
\hline \multicolumn{4}{|l|}{ Agglomeration* } \\
\hline$\bullet \#$ of FDI & $(-)$ & Not significant. & Not significant \\
\hline & $(+)$ & $(+)$ & $(+)$ \\
\hline - Same Sector & $(+)$ & $(+)$ & $\begin{array}{c}(+) \\
\text { Only for } \\
\text { PRODUCTION FDI }\end{array}$ \\
\hline \multicolumn{4}{|l|}{ Dissimilarity parameters** } \\
\hline \multicolumn{4}{|l|}{\begin{tabular}{l|l} 
Sub-national drivers \\
\end{tabular}} \\
\hline - National drivers & $\begin{array}{l}\text { All remaining } \\
\text { countries }\end{array}$ & All remaining countries & $\begin{array}{l}\text { Most of remaining } \\
\text { countries are not } \\
\text { significant }\end{array}$ \\
\hline
\end{tabular}

Source: Authors' estimates in Tables 2 and 3.

$*(+)$ and $(-)$ reflect respectively positive and negative significant coefficients

$* *>0.3$ in Table 3 
APPENDIX

Table A-1 - Variables definitions and sources

\begin{tabular}{|c|c|c|}
\hline \multicolumn{2}{|l|}{ Dependent Variable } & Source(s) \\
\hline \multicolumn{2}{|c|}{ Location decisions of greenfield investments in the regions } & FDi Markets \\
\hline \multicolumn{3}{|c|}{ Explanatory variables } \\
\hline \multicolumn{3}{|c|}{ Characteristics of the host regions } \\
\hline Regional GDP per capita & & EUROSTAT \\
\hline Patents per capita & EPO patent applications per capita & EUROSTAT \\
\hline Social Filter & $\begin{array}{l}\text { The index combines, by means of Principal } \\
\text { Component Analysis (Table A-2), the variables } \\
\text { describing the socio-economic realm of the region } \\
\text { (listed below) }\end{array}$ & EUROSTAT \\
\hline Education Employed People & $\begin{array}{l}\text { \% Employed People with Tertiary Education Level } \\
\text { (Isced } 7979 \text { levels 5-7) }\end{array}$ & EUROSTAT \\
\hline Education Population & $\begin{array}{l}\text { \% Population with Tertiary Education Level (Isced } \\
79 \text { levels 5-7) }\end{array}$ & EUROSTAT \\
\hline Agricultural Labour Force & Agricultural employment as \% of total employment & EUROSTAT \\
\hline Long Term Unemployment & Long term unemployed as \% of total unemployment. & EUROSTAT \\
\hline Regional Unemployment Rate & & EUROSTAT \\
\hline \multicolumn{3}{|c|}{ Agglomeration indicators: for each region/investment pair } \\
\hline Total \# of Investments & $\begin{array}{l}\text { Cumulative \#of total FDI in the region (all sectors, } \\
\text { all functions) }\end{array}$ & fDi Markets \\
\hline $\begin{array}{l}\text { Total \# of investments same } \\
\text { FUNCTIONS }\end{array}$ & $\begin{array}{l}\text { Cumulative \# of FDI in the region in the same } \\
\text { FUNCTION as the investment under analysis }\end{array}$ & fDi Markets \\
\hline $\begin{array}{l}\text { Total \# of investments same } \\
\text { SECTOR }\end{array}$ & $\begin{array}{l}\text { Cumulative \# of FDI in the region in the same sector } \\
\text { as the investment under analysis }\end{array}$ & fDi Markets \\
\hline
\end{tabular}


Table A-2 - 'Social Filter' Index - Results of the Principal Components Analysis (PCA) Table A-2.1- PCA Eigen Analysis of the Correlation Matrix

\begin{tabular}{|l|c|c|c|c|}
\hline \multicolumn{5}{|c|}{ EU 25 } \\
\hline Comp1 & 2,30323 & 1,3384 & 0,5758 & 0,5758 \\
\hline Comp2 & 0,964829 & 0,250263 & 0,2412 & 0,817 \\
\hline Comp3 & 0,714565 & 0,697188 & 0,1786 & 0,9957 \\
\hline Comp4 & 0,0173775 &. & 0,0043 & 1 \\
\hline
\end{tabular}

Table A-2.2 - PCA: Principal Components' Coefficients

\begin{tabular}{|l|c|c|c|c|}
\hline \multicolumn{5}{|c|}{ EU 25 } \\
\hline $\begin{array}{l}\text { Agricultural Labor } \\
\text { Force }\end{array}$ & $-0,4009$ & 0,3471 & 0,8478 & 0,0046 \\
\hline $\begin{array}{l}\text { Long Term } \\
\text { Unemployment }\end{array}$ & $-0,2662$ & 0,8389 & $\begin{array}{c}- \\
0,4697\end{array}$ & 0,0686 \\
\hline Education Population & 0,6271 & 0,2478 & 0,1912 & 0,7133 \\
\hline $\begin{array}{l}\text { Education Employed } \\
\text { People }\end{array}$ & 0,6125 & 0,3381 & 0,1549 & $\begin{array}{c}- \\
0,6975\end{array}$ \\
\hline
\end{tabular}




\section{The UNU-MERIT WORKING Paper Series}

2015-01 How does firms' perceived competition affect technological innovation in Luxembourg? by Wladimir Raymond and Tatiana Plotnikova

2015-02 The effect of supplementation with locally available foods on stunting. A review of theory and evidence by Mutinta Nseluke Hambayi, Wim Groot and Nyasha Tirivayi

2015-03Ethnic divisions, political institutions and the duration of declines: A political economy theory of delayed recovery Richard Bluhm and Kaj Thomsson

2015-04 Offshoring of medium-skill jobs, polarization, and productivity effect: Implications for wages and low-skill unemployment by Ehsan Vallizadeh, Joan Muysken and Thomas Ziesemer

2015-05 Risk preference or financial literacy? Behavioural experiment on index insurance demand by Yesuf M. Awel and Théophile T. Azomahou

2015-06 Poverty persistence and informal risk management: Micro evidence from urban Ethiopia by Théophile T. Azomahou and Eleni A. Yitbarek

2015-07Research joint ventures in an R\&D driven market with evolving consumer preferences: An evolutionary multi-agent based modelling approach by Salih Çevikarslan

2015-08 The effects of remittances on support for democracy in Africa: Are remittances a curse or a blessing? by Maty Konte

2015-09 The location strategies of multinationals from emerging countries in the EU regions by Riccardo Crescenzi, Carlo Pietrobelli and Roberta Rabellotti 